ОСОБЛИВОСТІ РОЗВИТКУ СВІТОВОГО ГОСПОДАРСТВА ТА МЕВ

339.924(477):061.1€C]:339.548(470+571)

\title{
ECONOMIC INTEGRATION OF UKRAINE WITH THE EU UNDER DISINTEGRATION WITH RUSSIA
}

\author{
ЕКОНОМІЧНА ІНТЕГРАЦІЯ УКРӒ̈НИ 3 СС \\ В УМОВАХ ДЕЗІНТЕГРАЦІї 3 РОСІЕЮ
}

\section{ЭКОНОМИЧЕСКАЯ ИНТЕГРАЦИЯ УКРАИНЫ С ЕС В УСЛОВИЯХ ДЕЗИНТЕГРАЦИИ С РОССИЕЙ}

\section{Shnyrkov O. I.}

Doctor of Economic Sciences, Professor, Head of the Department of World Economy and International Economic Relations. of Taras Shevchenko National University of Kyiv. E-mail: aisch@ukr.net

\section{Chugaiev O. A.}

$\mathrm{PhD}$ (Economics), Associate Professor of the Department of World Economy and International Economic Relations of Taras Shevchenko National University of Kyiv. E-mail: alxcv@ukr.net

\section{Шнирков О. I.}

Доктор економічних наук, професор, завідувач кафедри світового господарства і міжнародних економічних відносин Інституту міжнародних відносин Київського національного університету імені Тараса Шевченка. E-mail: aisch@ukr.net

\section{Чугасв О. А.}

Кандидат економічних наук, доцент, доцент кафедри світового господарства і міжнародних економічних відносин Інституту міжнародних відносин Київського національного університету імені Тараса Шевченка. E-mail: alxcv@ukr.net

\section{Шнырков А. И.}

Доктор экономических наук, профессор, заведующий кафедрой мирового хозяйства и международных экономических отношений Института международных отношений Киевского национального университета имени Тараса Шевченко. E-mail: aisch@ukr.net

\section{Чугаев А. А.}

Кандидат экономических наук, доцент, доцент кафедры мирового хозяйства и международных экономических отношений Института международных отношений Киевского национального университета имени Тараса Шевченко. E-mail: alxcv@ukr.net

Abstract. The purpose of research is to analyze the reasons and effects of disintegration with Russia for Ukraine and its association with the EU. Expected results of the Association Agreement with the EU and conflict with Russia in previous research are compared with the actual effects. Export losses of the opposing countries from the economic conflict are calculated and compared. The EU-Ukraine Association Agreement has marked the choice of Ukraine to follow the European social and economic development model. It aimed at decreasing trade barriers, making reforms and engaging Ukraine in international production networks by foreign investment inflows. But the EU and Ukraine did not foresee the severe economic, political and mili- 
tary reaction of Russia, which is a barrier to efficient implementation of the Association Agreement. Decrease in exports to Russia and other CIS countries has not been offset by better access to the EU market. Severe reaction of Russia is politically motivated and is not substantiated economically. All the conflicting parties faced losses from the economic war. Ukraine and Russia were the most affected countries, while Western countries faced minor losses. Restoring cooperation and integration is not possible without changes in foreign policy of Russia or / and other parties.

Key words: European economic integration, association agreement, economic disintegration, economic sanctions, economic war, foreign trade.

Анотація. Метою дослідження є аналіз причин та наслідків дезінтеграчї Украӥни $i$ Росії та асоціачії України з СС. Очікувані результати Угоди про асоціацію з СС $і$ конфлікту з Росією у попередніх дослідженнях порівнюються з фактичними наслідками. Розраховані і порівнюються втрати для експорту краӥн-учасниць економічного конфлікту. Угода про асочіачію Украӥни з СС позначила вибір Украйни слідувати європейській моделі сочіально-економічного розвитку. Вона мала на меті зниження торговельних бар'єрів, проведення реформ і залучення Украӥни в міжнародні виробничі мережі шляхом залучення іноземних інвестицій. Але СС $і$ Украӥна не передбачили суворої економічної, політичної та військової реакиї з боку Росії, щуо стало бар'єром на шляху ефективної імплементаиії Угоди про асоиіацію. Покращання доступу на ринок $Є С$ не компенсувало скорочення експорту до Росї та інших країн СНД. Сувора реакиія Росії є політично мотивованою і не обтрунтована економічно. Всі конфліктуючі сторони несуть втрати від економічної війни. Украйна і Росія понесли найбільші втрати, у той час як західні крайни відчули значно менші втрати. Відновлення співробітництва та інтеграцї неможливе без зміни зовнішньої політики Росії та /або інших сторін.

Ключові слова: європейська економічна інтеграція, угода про асоціацію, економічна дезінтеграція, економічні санкиії, економічна війна, міжнародна торгівля.

Аннотация. Целью исследования является анализ причин и последствий дезинтегращии Украины и России и ассощииации Украины с ЕС. Ожидаемые результаты Соглашения об ассочииаџии с ЕС и конфликта с Россией в предылдущих исследованиях сравниваются с фактическими последствиями. Рассчитаны и сравниваются потери для экспорта стран-участнии экономического конфликта. Соглашение об ассоциации Украины с ЕС обозначила выбор Украины следовать европейской модели сочииально-экономического развития. Она имела иелью снижения торговых барьеров, проведения реформ и привлечения Украины в международные производственные сети путем привлечения иностранных инвестиций. Но ЕС и Украина не предусмотрели жесткой экономической, политической и военной реакции со стороны России, что стало барьером на пути эффективной имплементащии Соглашения об ассоџиаџии. Улучшение доступа на рынок ЕС не компенсировало сокращение экспорта в Россию и другие страны СНГ. Жесткая реакция России является политически мотивированной и не обоснована экономически. Все конфликтуюшие стороны несут потери от экономической войны. Украина и Россия понесли наибольшие потери, в то время как западные страны ощутили значительно меньшие потери. Восстановление сотрудничества и интеграции невозможно без изменения внешней политики России и / или других сторон.

Ключевые слова: европейская экономическая интеграция, соглашение об ассоциаици, экономическая дезинтеграция, экономические санкции, экономическая война, международная торговля. 
Introduction. Ukraine as an open economy is objectively interested in developing mutually beneficial economic relations with its partner countries. The Association Agreement between Ukraine and the EU (AA) [European Atomic Energy Community, European Union, The Member States, Ukraine: 2014] aimed at enlarging the area, where Ukrainian exporters can trade with minimal barriers and at implementing best-practice standards of the EU economic regulation in Ukraine. But in 2014 traditionally skeptical attitude of Russian Federation towards European aspirations of Ukraine transformed into a confrontation, which also resulted in tension between Russia and Western countries. Economic and political reaction of Russia turned out to be excessively hard relatively the potential risks of the AA for its economy. As a result the expected benefits of the Deep and Comprehensive Free Trade Area between the EU and Ukraine (DCFTA) could not be fully exploited under the shrinking market, disintegration with Russia and downward trends in foreign investments.

The purpose of research is to analyze the reasons and effects of disintegration with Russia for Ukraine and its association with the EU.

Analysis of the latest publications. There is a large variety of works analyzing the effects of trade liberalization between Ukraine and the EU, e.g. [Brenton: 2000; Emerson et al.: 2006; ECORYS: 2010; Frey and Olekseyuk-Viber: n.d.; Maliszewska, Orlova and Taran: 2011; Movchan and Shportyuk: 2011; Shepotylo: 2010; The Institute for Economic Research and Policy Consulting: 2011]. They used various methods, assumed various depth of integration, and provided different estimated effects. In most cases the works pay more attention to the effects of tariff liberalization, avoid accounting for change in demand and supply elasticities or correlation between various factors of economic growth. Sometimes the estimated effects are close to statistical error. On the other hand, deep integration (at least DCFTA and customs unions) should be treated as a part of regional models of social, economic and political development. Therefore decisions about deep integration should not be rationalized by trade liberalization only.

Oxford Economics analyzed the effects of various types of integration scenarios between Ukraine and the EU. Ukrainian researchers were a part of their team. They considered three scenarios: classical FTA, DCFTA and Customs Union with the EU. All the scenarios would provide substantial benefits for Ukraine. DCFTA was assessed as the most beneficial realistic scenario. But the authors stated that the large benefits would appear only if Ukraine made economic reforms and approximated its regulatory environment to the EU (by the way, one of the reasons of the recent financial crisis in Southern Europe was weak government policy and slow adaptation of the real and financial sectors to new conditions of regional and global competition). The main beneficiaries would be textile and food industries, construction, agriculture and trade. Smaller effects would be for mining, chemical and metallurgy industry [Oxford Economics: 2012].

Thus the majority of works that we know evidence in favor of positive effects of the AA. But mostly they did not assumed the severe reaction of Russia. The EU also did not foresee such a reaction and was not ready for it.

Oxford Economics: 2012 was one of the first research works to consider possible effects of Russian reaction to the AA. Under several assumptions economic pressure of Russia would have a negative impact on Ukrainian economy during 4-5 years. It would curb consumption and investment flows [Oxford Economics: 2012].

Therefore under scenario of signing the AA Russia could substantially influence economic development of Ukraine. It could curb economic growth or even initiate a crisis. Positive effects of DCFTA would not offset completely the new Russian trade barriers in the short and 
middle-term period. The loss-to-benefit ratio would depend on the depth of integration with the EU, types of measures used by Russia and efficiency of adjustment of Ukrainian economy.

P. Havlik stated that if Russia used trade measures against Ukraine, the most sensitive industry would be machine building mostly located in the Eastern Ukraine [Havlik: 2014]. L. V. Shynkaruk forecasted losses for Ukrainian exports ( $\$ 4.6$ billion) and imports ( $\$ 2.1$ billion). Negative impact on GDP would be between -0,8\% and -0,5\% [Shynkaruk: 2014]. S. Kulik, A. Spartak, E. Vinokurov and I. Yurgens estimated losses of Ukraine as high as $\$ 33$ billion per year in the coming years under worsening relations with Russia and the EAEU [Kulik et al.: 2014]. Therefore we see that better access to the EU market under the AA would not compensate the loss of the CIS markets as a result of hard measures of Russia.

Experts of Higher School of Economics and Central Bank of Russia estimated the losses from sanctions to be $\$ 170$ billion during 3 years. A. Kudrin compared the losses with the cost of Olympic games in Sochi: at least $\$ 200$ billion during 2-3 years [РБК daily: 2014]. The estimates of the Ministry of Finance of Russia were $\$ 40$ billion from sanctions and \$90-100 billion from low oil prices. The European Commission's estimates envisaged lower GDP growth by $0.6 \%$ in 2014 and by $1.1 \%$ in 2015 . According to Dealogic, Russian bond issuers were able to receive only $\$ 9.5$ billion at the international markets in 2014 ( $\$ 53$ billion in 2013), equity issuers - $\$ 1.9$ billion ( $\$ 10.3$ billion) [Ткачев, Сухаревская: 2014]. B. M. Cheskidov claimed that financial sanctions were the biggest burden as they negatively affected investment attractiveness and the ability to refinance existing debt. Other problems were the burden to finance the Crimea and Sevastopol, higher military costs and investments in import substitution [Ческидов: 2014].

The important research results. The EU and EAEU as competing and complementary integration projects and integration policy of Ukraine. The fundamental reason for economic opposition in the EU-Ukraine-Russia triangle is existence of competing integration attractors Western Europe and Russia. The EU and EAEU (Eurasian Economic Union) are often considered to be rival integration blocs, especially in Eastern Europe. But we also can treat them as complementary blocs, which in some scenarios can increase efficiency of each other.

Under establishment of megaregional and interregional integration blocs, countries and blocs based on closed regionalism tend to face the risk of trade diversion effect. The EU signed preferential trade agreements with various countries to become a ramified integration hub in order to decrease the risk of trade diversion. The EAEU also seeks to use a similar approach, but it is a much less ramified integration bloc. Considering geographical proximity many third countries tend to seek a cross-membership in FTAs (free trade areas) with the EU and EAEU or other blocs.

Foreign trade of Ukraine used to be almost equally divided into trade with the CIS, EU and the rest of the world. Ukraine enjoyed free trade with the CIS countries. DCFTA provided free trade regime for another important part of foreign trade of Ukraine. Instead of enlarging trade diversion, DCFTA rather decreased trade diversion caused by the CIS FTA. As a result in 2014$1559 \%$ of Ukrainian exports enjoyed free trade regime because of various FTAs and the EU autonomous preferential treatment [Бураковський et al.: 2016].

Nowadays it is preferable for Ukraine to have FTAs both with the EU and the CIS countries and to minimize negative reaction of Russia to the AA. Other regional integration scenarios (without AA with the EU) were also possible, but they are second best scenarios because of curbing structural changes and economic modernization especially in the long run. They would preserve the periphery status of Ukrainian economy.

The ideal scenario of a network of FTAs between Ukraine and all its main trade counterparties (including between the EU and EAEU) would also decrease the risks of political and economic confrontation. M. Emerson: 2014 considered a moderately deep FTA between the EU 
and EAEU as a realistic scenario. It could be a solution for Ukraine, which would benefit from westward and eastward integration [Emerson: 2014].

Traditional disincentives for creating the EU - EAEU FTA were trade structure and tariff escalation. All other things being equal, exporters of raw materials (or energy goods in case of Russia) tend to face lower import tariffs, than the EU exporters of manufactured goods face in the EAEU customs union. This would shift cost to benefit ratio of the FTA in favor of the EU. But energy prices and devaluation decreased importance of this disincentive. Also national interests are something larger than government revenue: they include interests of consumers and investors, who buy imported goods [Emerson: 2014]. On the contrary the effect of larger benefits of trade integration for relatively smaller economies would favor the EAEU.

But nowadays an important disincentive is political and economic tension at least within the following dyads: Western countries - Russia, Russia - Ukraine, "mainland Ukraine" - uncontrolled territories (the Crimea and regions under anti-terrorist operation). The modern confrontation was preceded by trade wars, but they were local and affected few industries. Nowadays more than 50 countries in various continents participate in the economic war affecting wide range of industries [Будкін: 2014].

Motivation for reaction of Russia to the Association Agreement. Russia declared about several economic risks of the AA for its economy:

- importing goods from the EU, which could formally be considered as Ukrainian;

- large inflow of Ukrainian goods, which would be uncompetitive with the European ones;

- adoption of the EU technical regulations by Ukraine would hinder traditional trade flows between Russia and Ukraine;

- erosion of Russia's goods competitiveness at the Ukrainian market;

- partial deprivation of Ukraine's economic sovereignty in favor of the EU institution;

- impossibility for Ukraine to join the EAEU customs union.

The declared risks are mainly based on possible negative trade diversion effect for Russian producers. Indeed it can happen, but it is rather small [Shnyrkov, Rogach and Chugaiev: 2015] and can be offset by a potential EU - EAEU FTA, investments in modernization, harmonization or mutual recognition of technical regulations and growth of effective demand in the EU and Ukraine. Therefore objections of Russian Federation to the AA were mainly politically motivated, and not economically. It wanted Ukraine to join the EAEU. Meanwhile other EAEU Member States has not declared official objections to the EU - Ukraine AA.

Actual effects of confrontation. Thus the negative economic reaction of Russia to the EUUkraine AA could be predicted. Its absence would be rather an optimistic scenario. But military and political reaction of Russia was unexpected. It substantially worsened the investment potential of Ukraine. We should note that European and other foreign investments were expected to help Ukraine to adjust its economy to implementation of the EU regulations. Partial facilitation was provided by the EU autonomous preferential treatment in 2014-15, international assistance and falling energy prices.

All the participants of the economic war and even third countries suffer losses from it. Considering economies of scale, in all the dyads (Western countries - Russia, Russia - Ukraine, mainland Ukraine - uncontrolled territories) smaller parties face disproportionally larger losses. They include:

- transformation costs (due to changes in regulation and redirection of trade flows);

- transaction costs (increased formal and informal trade barriers).

They explain artificial trade diversion effect due to restrictive trade and financial measures (actually economic disintegration) and uncertainty. This effect may not be compensated by trade 
creation effect in the middle-term perspective (for Ukraine - by the AA with the EU and FTAs with third countries, for the EAEU - by enlargement and FTAs with third countries).

Restrictive economic measures. The recent 10 years was a period of gradual exacerbation of economic disintegration between Russia and Ukraine. The most recent 2 years was a time of deep crisis in the bilateral economic relations. The disintegration was marked by:

- hybrid economic war of Russia against Ukraine;

- mutual economic sanctions;

- forced integration of the Crimea and part of Donbas to the EAEU;

- MFN instead of free trade treatment of Ukrainian exports in Russia since January 1, 2016.

The hybrid economic war of Russia aiming at retarding reforms and deepening social and economic crisis in Ukraine includes the following components:

- more than 40 trade wars and 4 gas wars against Ukraine in 2004-16;

- breaking subregional production networks with Ukrainian companies in industry and agriculture;

- increasing external debt of Ukraine by holding up gas prices and refusing to restructure part of the debt;

- affecting devaluation of hryvnia;

- new restriction and barriers for Ukrainian labor since 2015;

- destroying enterprises and partial occupation of Donbas region as an anchor to retard European integration of Ukraine (about 8 thousand people were killed, $1.5 \mathrm{mln}$. persons were temporarily displaced, $25 \%$ enterprises stopped operation, $10 \%$ plants were destroyed, rebuilding the destroyed enterprises would cost $\$ 1.5$ billion; military actions can recommence at any time, which blocks national and foreign investments);

- increased military expenditure in Ukraine instead of financing improvements in the social, infrastructural and other civilian sectors;

- restrictions on transit of Ukrainian goods to the Central Asian countries.

E.g. in 2014 over $90 \%$ Ukrainian exports to Russia were discriminated in various forms. Under MFN treatment instead of free trade, Ukraine could suffer more from asymmetric tariff barriers. MFN tariffs are higher in Russia than in Ukraine for bilateral trade flows [World Trade Organization: n.d.].

At the same time it was more difficult for Ukraine to apply restrictive measures against Russia because:

- Ukraine depended more on Russian market than Russia's dependence on Ukrainian one;

- Ukrainian economy is more open and therefore more vulnerable to economic disintegration;

- thus Ukraine would suffer more from distortion of prices and decreasing foreign trade;

- Russia had better margin of safety at least earlier under higher energy prices;

- retaliation by Ukraine could provoke Russia to use more severe measures.

Moreover G. C. Hufbauer, J. J. Schott, K. A. Elliott and B. Oegg stated that economic sanctions are more efficient against small countries. In their sample the median ratio of the initiator country's GDP to the target country's GDP was 105 [Hufbauer et al.: 2007]. Ukrainian restrictions of financing Russian banks, high-tech exports, entrance of Russian celebrities, and imposing fines for flights to the Crimea can have only a minimal effect [Беррес: 2014].

It was an economic rationalization for lagging in launching economic sanctions by Ukraine. But a more efficient measure is joining sanctions of Western countries. In this case the initiator countries' GDP to the target country's GDP ratio is not favorable for Russia. Although the effect of those sanctions was limited by the following factors: 
- limited range of target entities and economic sectors;

- interdependence of Russia and Western countries;

- political and ideological influence of Russia;

- Western countries are not ready to use military force or other non-economic actions [Sharov: 2015].

But efficiency of the sanctions will probably increase as they continue. But lack of accord in the EU Member States considering support of the sanctions questions the effectiveness of the AA implementation. Nowadays the sanctions against Russia have achieved the effect of joint responsibility of the country, but have not achieved the political objective to settle the conflict and to ensure personal responsibility. But they managed to stop escalation of breach of territorial integrity of Ukraine and are a disincentive for further similar violations of the international law globally in the future. Easing or cancellation of the sanctions would be a barrier to the efficient implementation of the AA.

Economic losses of Ukraine. A smaller and more open economy of Ukraine suffers from relatively larger losses. Post factum we may say that the deep economic crisis in 2014-15 in Ukraine was largely caused by discriminatory economic actions, military operations and political pressure of Russia, as well as by accumulated internal economic and political problems. The GDP fell by $6.5 \%$ and $9.9 \%$ in 2014-15. As a result of devaluation inflation reached $25 \%$ and $43 \%$ respectively. Unemployment reached $9.5 \%$. But the current account deficit almost disappeared in 2015 thanks to the devaluation of hryvnia [International Monetary Fund: 2016].

During several years Ukraine lost $\$ 98$ billion mainly as a result of Russian restrictions [WTO: 2016]. In 2016 only 42\% Ukrainian exports enjoyed free trade instead of 59\% in 2015. Exports of agricultural products, metals and machines turned out to be the most vulnerable [The IER, Sergii Koziakov \& Partners Law Firm: 2016].

As for uncontrolled territories of Ukraine, they are de facto separate small economies. As a result of military and political risks, at best these territories can use the MIRAB strategy (migration, remittances, aid and bureaucracy - according to the definition by [Baldacchino and Bertram: 2009]) instead of the strategies of more successful small economies based on tourism, financial services, niche production, transport services, resource management, and advantages of citizenship and residency. Absence of reliable statistical data does not allow us to apply a more detailed analysis in this case.

Under these circumstances economic recovery in Ukraine is possible as a result of fast and efficient regulatory convergence with the EU, at least stabilization of demand for Ukrainian goods and services in the EU and third countries. But the issue of efficient adjustment of Ukrainian producers and consumers to the EU regulations remain topical (cost-to-benefit ratio).

Nowadays the benefits of the AA still do not offset the losses caused by actions of Russian. In 2015 (base year - 2013) Ukrainian export to Russia decreased by $\$ 10$ billion, to other CIS countries - by $\$ 4$ billion. On the other hand, the EU planned to provide $\$ 11$ billion of financial aid in 2014-2020 (from the EU budget, EIB and EBRD). But bilateral trade with the EU decreased by $\$ 15$ billion (although the EU share increased from $32.2 \%$ to $37.5 \%$ ), the Ukrainian exports to the EU decreased by $\$ 3.8$ billion (the EU share increased from $26.5 \%$ to $34.1 \%$ ). We observe a relative redirection of Ukrainian exports to the EU and the rest of the world from Russia, instead of absolute redirection under stable exports. There were also structural changes in the Ukrainian exports to the EU. The share of agricultural products and machines increased at the expense of decreasing share of mineral and metal products [Emerson and Movchan: 2016].

Economic losses of Russian Federation. Our estimates of Russia's losses from shrinking market in Ukraine (largely due to Russian actions) include decrease in exports to the mainland Ukraine by $\$ 9$ billion in 2014 and $\$ 13$ billion in 2015 (base year - 2013) and decrease in trade 
surplus by $\$ 6$ billion and $\$ 7$ billion respectively (calculations based on [State Statistics Service of Ukraine: 2016]). In these estimates we tried to account for the loss of territorial integrity. We should state that these losses have not been caused by the AA, because Ukraine provided partial free trade treatment for the EU exports only in 2016. Thus losses of Russia from its actions are several times larger than its potential losses from the AA. The actual losses from the AA will be even smaller because Ukrainian market already had shrunk before 2016. Russian exports to Ukraine decreased as a result of worse image of Russia, trade restrictions, lower demand, cheaper labor and devaluation of hryvnia in Ukraine. In 2014 the most vulnerable exports from Russia to Ukraine turned out to be products of energy, chemical and shipbuilding industries [UNCTADStat: 2016].

But the largest losses were caused by sanctions of Western countries, falling oil and gas prices, growing military expenditure, costs to support the occupied territories, and worsening investment potential. The GDP growth in Russia slowed down to $0.7 \%$ in 2014 and became negative $(-3.7 \%)$ in 2015 . Inflation increased to $13 \%$ in 2015 . However the trade surplus increased to $5 \%$ GDP as a result of ruble devaluation and decreasing imports (IMF 2016). Thus the total losses of Russia from economic war are several dozens times larger than its potential losses from the AA. Besides direct economic losses, Russia suffers from worsening reputation. It is treated as an unsafe and unpredictable partner. All these facts show that the decision of Russia to start a massive hybrid economic war against Ukraine is not substantiated economically.

Estimation of losses at the Ukrainian and Russian markets adjusted for size of economies. In Table 1 we provide results of our calculations of losses in a sample of countries (Ukraine, the EU and EAEU Member States and several large countries). We calculated fall in exports to Ukraine and Russia in 2015. We used 3 types of indicators: in \% of exports in 2013, in billion dollars and in \% of GDP (exchange rate based) in 2013. We have not adjusted for loss of territorial integrity.

Table 1

Export losses of countries from shrinking of the Ukrainian and Russian markets (2015 to 2013)

\begin{tabular}{|l|r|r|r|c|c|c|c|}
\hline \multirow{2}{*}{ Country } & \multirow{2}{*}{$\begin{array}{c}\text { GDP, \$ } \\
\text { bln, 2013 }\end{array}$} & $\begin{array}{c}\text { Losses in Ukrainian market } \\
\text { \% exports } \\
\text { in 2013 }\end{array}$ & \$ bln & \% GDP & $\begin{array}{c}\text { Losses in Russian market } \\
\text { in 2013 }\end{array}$ & \$ bln & \% GDP \\
\hline Ukraine & 180 & - & - & - & 68 & 10.24 & 5.70 \\
\hline Russian Federation & 2232 & 61 & 14.52 & 0.65 & - & - & - \\
\hline Austria & 429 & 59 & 0.55 & 0.13 & 49 & 2.83 & 0.66 \\
\hline Belgium & 522 & 54 & 0.55 & 0.11 & 50 & 3.41 & 0.65 \\
\hline Bulgaria & 56 & 64 & 0.36 & 0.65 & 43 & 0.33 & 0.60 \\
\hline Croatia & 58 & 57 & 0.02 & 0.03 & 43 & 0.16 & 0.28 \\
\hline Cyprus & 24 & 51 & 0.01 & 0.03 & 69 & 0.02 & 0.09 \\
\hline Czech Republic & 208 & 63 & 1.05 & 0.50 & 47 & 2.77 & 1.33 \\
\hline Denmark & 339 & 56 & 0.22 & 0.06 & 60 & 1.25 & 0.37 \\
\hline Estonia & 25 & 54 & 0.07 & 0.29 & 54 & 1.02 & 4.03 \\
\hline Finland & 270 & 53 & 0.25 & 0.09 & 51 & 3.62 & 1.34 \\
\hline France & 2811 & 49 & 0.62 & 0.02 & 51 & 5.20 & 0.18 \\
\hline Germany & 3746 & 54 & 3.85 & 0.10 & 49 & 23.33 & 0.62 \\
\hline Hungary & 134 & 45 & 1.18 & 0.88 & 50 & 1.69 & 1.25 \\
\hline Greece & 240 & 14 & 0.04 & 0.02 & 56 & 0.30 & 0.13 \\
\hline
\end{tabular}




\begin{tabular}{|c|c|c|c|c|c|c|c|}
\hline \multirow[b]{2}{*}{ Country } & \multirow{2}{*}{$\begin{array}{c}\text { GDP, \$ } \\
\text { bln, 2013 }\end{array}$} & \multicolumn{3}{|c|}{ Losses in Ukrainian market } & \multicolumn{3}{|c|}{ Losses in Russian market } \\
\hline & & \begin{tabular}{|c|}
$\%$ exports \\
in 2013
\end{tabular} & $\$$ bln & $\%$ GDP & $\begin{array}{l}\text { \% exports } \\
\text { in } 2013\end{array}$ & \$ bln & $\%$ GDP \\
\hline Ireland & 238 & 60 & 0.06 & 0.02 & 52 & 0.43 & 0.18 \\
\hline Italy & 2131 & 60 & 1.48 & 0.07 & 45 & 6.42 & 0.30 \\
\hline Latvia & 30 & 38 & 0.06 & 0.21 & 41 & 0.96 & 3.18 \\
\hline Lithuania & 46 & 37 & 0.42 & 0.90 & 46 & 2.99 & 6.44 \\
\hline Luxemburg & 62 & 69 & 0.02 & 0.03 & 40 & 0.08 & 0.13 \\
\hline Malta & 10 & 62 & 0 & 0 & 92 & 0.04 & 0.42 \\
\hline Netherlands & 864 & 54 & 0.87 & 0.10 & 49 & 5.21 & 0.6 \\
\hline Poland & 524 & 42 & 2.40 & 0.46 & 47 & 5.08 & 0.97 \\
\hline Portugal & 226 & 27 & 0.01 & 0 & 50 & 0.17 & 0.08 \\
\hline Romania & 192 & 73 & 0.94 & 0.49 & 40 & 0.74 & 0.38 \\
\hline Slovakia & 98 & 46 & 0.29 & 0.30 & 50 & 1.70 & 1.74 \\
\hline Slovenia & 48 & 62 & 0.22 & 0.46 & 40 & 0.62 & 1.31 \\
\hline Spain & 1370 & 54 & 0.3 & 0.02 & 50 & 1.88 & 0.14 \\
\hline Sweden & 579 & 25 & 0.09 & 0.01 & 52 & 1.88 & 0.32 \\
\hline The U.K. & 2713 & 50 & 0.42 & 0.02 & 40 & 2.5 & 0.09 \\
\hline Armenia & 11 & 59 & 0.01 & 0.08 & 32 & 0.11 & 0.98 \\
\hline Belarus & 73 & 40 & 1.67 & 2.29 & 38 & 6.45 & 8.82 \\
\hline Kazakhstan & 232 & 83 & 1.7 & 0.73 & - & - & - \\
\hline Kyrgyz Republic & 7 & 51 & 0.01 & 0.07 & 35 & 0.04 & 0.48 \\
\hline Canada & 1837 & 19 & 0.04 & 0 & 67 & 0.9 & 0.05 \\
\hline China (mainland) & 9519 & 55 & 4.33 & 0.05 & 30 & 14.8 & 0.16 \\
\hline India & 1863 & 48 & 0.23 & 0.01 & 27 & 0.6 & 0.03 \\
\hline Japan & 4909 & 64 & 0.37 & 0.01 & 53 & 5.88 & 0.12 \\
\hline The U.S. & 16663 & 55 & 1.07 & 0.01 & 36 & 4.06 & 0.02 \\
\hline Turkey & 823 & 49 & 1.07 & 0.13 & 48 & 3.37 & 0.41 \\
\hline
\end{tabular}

Source: authors' calculations based on [IMF: 2016; IMF: n.d.].

The largest losses in the Ukrainian market were in Kazakhstan, Romania and Luxemburg (in \% of exports to Ukraine in 2013), Russia, China, Germany, Poland, Kazakhstan and Belarus (in billion dollars), Belarus, Lithuania, Hungary, Kazakhstan, Russia and Bulgaria (in \% of GDP). Canada, Malta and Portugal had the lowest export decrease relative to their GDP.

The largest losses in the Russian market were in Malta, Cyprus, Ukraine and Canada (in \% of exports to Russia in 2013), Germany, China, Ukraine, Belarus, Italy and Japan (in billion dollars), Belarus, Lithuania, Ukraine, Estonia, Latvia and Slovakia (in \% of GDP). The U.S., India and Canada had the lowest export decrease relative to their GDP.

Total relative export losses in Ukrainian and Russia market were the largest in Belarus (11.1\% of GDP), Lithuania (7.4\%), Ukraine (5.7\%), Estonia (4.3\%) and Hungary (2.1\%). Romania and Bulgaria had more export losses from shrinking of the Ukrainian market than from the Russian one. The largest losses in the Russian market relative to the Ukrainian one were in Malta, Canada, Sweden and Portugal, but these losses relatively their GDP were small enough.

The simple average of export losses of all the countries in our sample in the Ukrainian market was $0.25 \%$ GDP, in Russian market $-1.1 \%$ GDP. Thus nominally losses in the Russian market were 4 times larger than in the Ukrainian one. But considering the ratio of Russian to 
Ukrainian GDP (12.4 in 2013), the relative losses in the Ukrainian market were 3 times disproportionally larger.

We noticed that the largest losses are in small countries. Partially it is explained by the sample selection and distance: if we excluded large distant economies the correlation would be smaller, especially in case of Ukrainian market. The correlation between the losses in the Russian market (in \% of GDP) and log of GDP was -0.34 (it is the only significant correlation), in the Ukrainian market it was -0.24 . As for losses in \% of exports in 2013 the correlations are

-0.21 and -0.02 respectively. Therefore small economies are especially sensitive to the losses in the Russian market, while large economies are not. In Ukrainian market both large and small economies had similar export losses.

Comparative analysis of export losses of Russia and its main trade partners. Table 2 proves that asymmetry of size does not allow Ukraine to efficiently influence Russia with individual sanctions. Decrease of Russian exports to Ukraine was only $0.65 \%$ of Russian GDP. Moreover the decrease was caused mainly by fall in effective demand, loss of territorial integrity and worsening image of Russia instead of actions of Ukrainian government. In relative terms Ukraine suffered much more from economic disintegration with Russia (5.7\% GDP), although its absolute losses are $30 \%$ less than the Russian ones.

Table 2

Export losses of Russia in the markets of its main trade partners and the losses of its main trade partners in the Russian market (2015 to 2013)

\begin{tabular}{|l|c|c|c|c|c|c|}
\hline \multirow{2}{*}{ Trade partner } & \multicolumn{3}{|c|}{ Losses of Russia } & \multicolumn{3}{c|}{ Losses of trade partner } \\
\cline { 2 - 7 } & $\begin{array}{c}\text { \% exports } \\
\text { in 2013 }\end{array}$ & \$ bln & \% GDP & $\begin{array}{c}\text { \% exports } \\
\text { in 2013 }\end{array}$ & \$ bln & \% GDP \\
\hline EU & 42 & 117.89 & 5.28 & 48 & 76.64 & 0.39 \\
\hline China (mainland) & 20 & 7.02 & 0.31 & 30 & 14.80 & 0.16 \\
\hline The U.S. & 15 & 1.64 & 0.07 & 36 & 4.06 & 0.02 \\
\hline Ukraine & 61 & 14.52 & 0.65 & 68 & 10.24 & 5.70 \\
\hline Japan & 26 & 5.17 & 0.23 & 53 & 5.88 & 0.12 \\
\hline
\end{tabular}

Source: authors' calculations based on [IMF: 2016; IMF: n.d.].

But losses of Russia in other markets (owing to sanctions, falling oil and gas prices, worsening image etc.) were much larger. On one hand losses in \% of exports in 2013 were smaller in Russia than in its partners as a result of ruble devaluation. But if we consider losses relative to GDP, Russia suffers 2 times more than Japan and China, 3 times more than the U. S. and 13.5 times more than the EU. Thus Russia proved to be the most sensitive to export losses in the EU market. We also must note that trade between Russia and China decreased despite the declared shifting of Russian strategic interests to China.

Conclusions. The fundamental reason for political and economic confrontation in the WestUkraine-Russia triangle is the existence of two main integration attractors in Europe: Western Europe / the EU and Russia / the EAEU. Despite competition between them, they also have some complementary features. Under better geopolitical scenarios they could integrate with each other or at least benefit from open bloc trade creation effect instead of trade diversion and disintegration.

AA is only a minor challenge for Russian economy despite the fears expressed by Russian government. We considered structural difference of exports, incomplete preferential treatment, 
possibility to protect Russian producers with more civilized measures, and potential benefits for Russia from growing market in Ukraine under better geopolitical scenario.

But Russia had several times more export losses from its own actions against Ukraine and several dozens more losses caused by sanctions of Western countries, falling oil and gas prices, investments in import substitutions, high military expenditure and cost of supporting occupied territories. The largest damage was inflicted on energy sector, financial sector and defense industry. Devaluation of hryvnia and decreased wages in Ukraine have more negative effect on Russian exports than preferential treatment under the AA, although in the middle-term period. Worsening image of Russia is another negative effect for it, which is related to decreasing economic links of Russia and the rest of the world.

In the West-Ukraine-Russia triangle Ukraine suffered from the largest relative losses (especially for exports of agricultural products, metals and machines to Russia). Uncontrolled territories as the smallest economies are especially vulnerable. Thus benefits of better access to the EU market, its financial aid and new export destinations has not been able to offset the massive pressure of Russia.

Russia, China and Germany had the largest absolute losses from shrinking of the Ukrainian market; Belarus, Lithuania and Hungary - relatively their GDP. Germany, China and Ukraine had the largest absolute losses from shrinking of the Russian market; Belarus, Lithuania and Ukraine - relatively their GDP. The U.S. had the lowest losses among the large economies. Bulgaria and Romania had more losses form shrinking of the Ukrainian market than of the Russian one. On average countries lost 4 times more from shrinking of the Russian market than of the Ukrainian one (but disproportionally much more in the Ukrainian market considering asymmetry in size of Ukrainian and Russian economies). Shrinking of the Russian market inflicted damage mainly on small economies. In the Ukrainian market the difference between the effects on small and large economies was insignificant.

Ukraine suffered much more (relatively GDP) from bilateral disintegration than Russia, however the absolute export losses are larger in Russia. But Russia's relative losses from disintegration with its main trade partners are larger than losses of Ukraine in the Russian market. Relatively GDP Russia faced 3 times more damage than the U.S. and 13.5 times more than the EU, despite that the EU had the largest losses among the Western countries.

Revival of investment activity of domestic and foreign enterprises is a crucial factor of restoration of economic growth in Ukraine under development of integration and disintegration processes. The AA should be treated as an important instrument of Ukraine's integration into international production networks, because tariff liberalization only will not provide large positive effect for the national economy. Investors should be provided with the guarantee of territorial integrity, sovereignty and security of Ukraine. Unless it is guaranteed, there are serious risks for participation of Ukrainian enterprises in international production networks, and thus efficient implementation of the AA and DCFTA in particular can be questioned.

Settling the issue of territorial integrity of Ukraine and return to a non-confrontation in international economic relations could provide benefits for all the affected countries thanks to easing tension in international relations, decreasing trade diversion and better integration prospects. But it largely depends on the position of Russian Federation on supporting or de-escalation of the conflict.

It is important for Ukraine to have a cross-membership in FTA with its main trade partners including the EU and the CIS. In ideal scenario the EU-Ukraine AA could be a link between the EU and the EAEU as a pilot project on the way to their cooperation and integration. In particular a moderately deep FTA between the EU and EAEU could decrease stakes in geopolitical and geoeconomic struggle for Ukraine. 
Integration is also about values and institutions. There are two main models of social and economic development in the region: European and Eurasian ones, and Ukraine had to make a choice between them. By signing and implementing the AA instead of classical FTA Ukraine made also a choice in favor of the European development model.

\section{References}

1. European Atomic Energy Community; European Union; The Member States; Ukraine (2014) Association Agreement between the European Union and its Member States, of the one part, and Ukraine of the other part, <http://eur-lex.europa.eu/legal-content/EN/TXT/ $\mathrm{PDF} /$ ?uri=CELEX:22014A0529\%2801\%29\&rid=3>

2. Беррес Л. (2014) 'Украина пугает нестрашными санкциями' [Ukraine frightens with unscary sanctions], Московский комсомолеи, 167: 2.

3. Будкін В. C. (2014) 'Геополітичні та геоекономічні наслідки Російсько-Українського конфлікту' [Geopolitical and geoeconomic consequences of the Conflict between Russia and Ukraine], Актуальні проблеми міжнародних відносин 121(I): 201-209.

4. Бураковський I. et al. (2016) Біла книга. Як реалізувати експортний потенціал України за умов глобалізащії. Пропозищї щуодо політики сприяння розвитку українського ексnopmy [White book. How to apply export potential of Ukraine under globalization. Proposals for Ukrainian export development facilitation policy]. Київ : Інститут економічних досліджень і політичних консультацій, АО «АФ «Сергій Козьяков та Партнери», $<$ http://platforma-msb.org/wp-content/uploads/2016/06/White_book_export_ UKR_2016.pdf>

5. РБК daily (2014) 'Цена экономической войны' [Price of economic war], РБК daily 221: 3.

6. Ткачев И., Сухаревская А. (2014) 'Холодная экономическая война' [Cold economic war], РБК daily 242: 8.

7. Ческидов Б. М. (2014) 'Применение экономических санкций и принципы минимизации их воздействия' [Using economic sanctions and the principles of minimizing their impact], Финансы 11: 11-16.

8. Шинкарук Л. В. (2014) 'Економічний вимір участі України в інтеграційних процесах’ [Economic dimention of Ukjraine's participation in integration processes], Вісник Національної академії наук України 5: 56-61.

9. Baldacchino G., Bertram G. (2009) 'The Beak of the Finch: Insights into the Economic Development of Small Economies', The Round Table: The Commonwealth Journal of International Affairs 98 (401): 141-160, <http://doi:10.1080/00358530902757867>

10. Brenton P. (2000) Trade Policies in the EU and Ukraine: Implications for a Free Trade Agreement, Prepared under EES Project UK 26: Study on the economic feasibility, general economic impact and implications of a free trade agreement between the European Union and Ukraine according to the Partnership and Cooperation Agreement. Brussels.

11. ECORYS (2010) Trade Sustainability Impact Assessment for the FTA between the EU and Ukraine within the Enhanced Agreement. Rotterdam.

12. Emerson M. (2014) Trade Policy Issues in the Wider Europe - that Led to War and not yet to Peace, CEPS working document (398). Brussels: Centre for European Policy Studies.

13. Emerson M., Movchan V., eds. (2016). Deepening EU-Ukrainian Relations. What, Why and How? Brussels, London, Kyiv: Centre for European Policy Studies, Institute for Economic Research and Policy Consulting, Rowman \& Littlefield International.

14. Emerson, M. et al. (2006) The Prospects of Deep Free Trade between the European Union and Ukraine. Brussels: Center for European Policy Studies. 
15. Frey M., Olekseyuk-Viber Z. (n.d.) Effects of Trade Liberalization between the EU and Ukraine in a Computable General Equilibrium (CGE) Model, <http://www.etsg.org/ ETSG2011/Papers/Frey.pdf>

16. Havlik P. (2014) 'Vilnius Eastern Partnership Summit: Milestone in EU-Russia Relations - not just for Ukraine', Danube: Law and Economic Review (5): 21-51, <http:/doi:10.2478/ danb-2014-0002>

17. Hufbauer G. C., Schott J. J., Elliott K. A., Oegg B. (2007). Economic Sanctions Reconsidered. 3rd ed. Washington, D.C.: Peterson Institution for International Economics.

18. International Monetary Fund (2016) World Economic Outlook Database, April 2016 Edition, <http://www.imf.org/external/pubs/ft/weo/2016/01/weodata/index.aspx>

19. International Monetary Fund (n.d.) Direction of Trade Statistics, $<$ http://data.imf.org/?sk= 9D6028D4-F14A-464C-A2F2-59B2CD424B85>

20. Kulik S., Spartak A., Vinokurov E., Yurgens I. (2014) Two Integration Projects in Europe: Dead End of Struggle. MPRA Paper (61636), <http://mpra.ub.uni-muenchen.de/61636/>

21. Maliszewska M., Orlova I., Taran S. (2011) 'Deep Integration with the EU: Impact on Selected ENP Countries and Russia', in: M. Dabrowski, M. Maliszewsk (eds.) EU Eastern Neighbourhood: Economic Potential and Future Development. Berlin: Springer.

22. Movchan V., Shportyuk V. (2011) 'Between Two Unions: Optimal Regional Integration Strategy for Ukraine', Proceedings of the 13th Annual Conference of the European Trade Study Group (ETSG), Copenhagen, 8-10 September 2011. (13 ${ }^{\text {th }}: 2011$ : Copenhagen, Denmark). Copenhagen: ETSG, 2011.

23. Oxford Economics (2012) The Impact of an FTA between Ukraine and the EU, Prepared for the Foundation for Effective Governance. Oxford.

24. Sharov O. (2015) Economy of the EU: Sanctions against Russia and their Reverse Effect, Journal of European Economy 14(2): 166-182.

25. Shepotylo O. (2010). A Gravity Model of net Benefits of EU Membership: the case of Ukraine, Journal of Economic Integration 25(4): 676-702.

26. Shnyrkov O. I., Rogach O. I., Chugaiev O. A. (2015) 'Russia's Concerns for the EU-Ukraine Association: Myths and Realities', Journal Global Policy and Governance 4 (20): 33-49 $<$ http://doi10.14666/2194-7759-4-2-002>

27. State Statistics Service of Ukraine (2016) Statistical Information $<$ http://ukrstat.gov.ua/>

28. The Institute for Economic Research and Policy Consulting (2011) Ukraine's Trade Policy Choice: Pros and Cons of Different Regional Integration Options. Kyiv, <http://www.ier. com.ua/files/Projects/2010/2010_05/trade_pros_and_cons_2011-12-08_eng.pdf >

29. World Trade Organization (n.d.) Tariff Profiles, <http://stat.wto.org/TariffProfile/WSDBTariffPFView.aspx? Language $=\mathrm{E} \&$ Country $=\mathrm{UA} \% 2 \mathrm{cRU}>$

30. World Trade Organization (2016) Trade Policy Review Report by Ukraine, <https://www. wto.org/english/tratop_e/tpr_e/g334_e.pdf>

31. UNCTADStat (2016) Trade Structure by Partner, Product or Service-Category, $<$ http://unctadstat.unctad.org/wds/ReportFolders/reportFolders.aspx $>$ 